Opinion

\title{
Belatacept dosing in Lung Transplantation: is there a Method to the Madness?
}

Christine Pham ${ }^{1,}{ }^{*}$, Brett J Pierce ${ }^{1}$, Simon W Yau ${ }^{2}$, Georges J Youssef ${ }^{2}$, Ahmad Goodarzi ${ }^{2}$, Howard J Huang ${ }^{2}$

1. Department of Pharmacy, Houston Methodist Hospital, 6565 Fannin St., DB1-051, Houston, Texas, USA; E-Mails: cpham@houstonmethodist.org; bjpierce@houstonmethodist.org

2. Department of Medicine, Houston Methodist Hospital, 6445 Main St., Suite 26, Houston, Texas, USA; E-Mails: swyau@houstonmethodist.org; igyoussef@houstonmethodist.org; agoodarzi2@houstonmethodist.org; hjhuang@houstonmethodist.org

* Correspondence: Christine Pham; E-Mail: cpham@houstonmethodist.org

Academic Editor: Kamyar Afshar

Special Issue: Transplantation Pharmacology

OBM Transplantation

2021, volume 5, issue 3

doi:10.21926/obm.transplant.2103152
Received: July 09, 2021

Accepted: August 25,2021

Published: August 30,2021

\begin{abstract}
Data supporting the use of belatacept in non-abdominal organs are limited to case series and small cohorts involving patients requiring conversion due to $\mathrm{CNI}$ intolerance or contraindication. Review articles summarizing the efficacy of belatacept salvage therapy in lung transplantation have previously been published, however, dosing regimens are highly variable and uniform guidance is lacking. In this article, indications and considerations for belatacept use in lung transplant recipients are reviewed with a specific focus on dosing regimens. Utilization of standardized dosing protocols to guide belatacept conversion will both improve the ability to directly assess outcomes and provide the opportunity to improve future patient care. A suggested framework for dosing selection and timeline for cross titration is proposed herein.
\end{abstract}

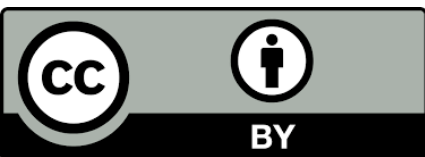

(C) 2021 by the author. This is an open access article distributed under the conditions of the Creative Commons by Attribution License, which permits unrestricted use, distribution, and reproduction in any medium or format, provided the original work is correctly cited. 


\section{Keywords}

Lung transplantation; belatacept; immunosuppression; dosing

\section{Introduction}

Belatacept is commonly used in kidney transplantation for maintenance immunosuppression as an alternative to calcineurin inhibitors (CNI) due to its more favorable metabolic profile, reduced chronic allograft nephropathy and incidence of de novo donor specific antibodies (DSAs), preservation of renal function, and improved long term patient and graft survival [1]. Belatacept was approved in 2011 by the US Food and Drug Administration (FDA) for use in combination with basiliximab induction, mycophenolate mofetil (MMF), and corticosteroids for prevention of rejection in adult kidney transplant recipients seropositive for Epstein-Barr virus (EBV) [2]. The immediate post-transplant labeled dose is $10 \mathrm{mg} / \mathrm{kg}$ intravenous (IV) on days 1 and 5, and weeks 2 , 4, 8 , and 12 post-transplantation, followed by $5 \mathrm{mg} / \mathrm{kg}$ every four weeks thereafter. This dosing scheme was used in the BENEFIT and BENEFIT-EXT studies, leading to its approval for de novo use. While both of these studies showed superior renal and metabolic outcomes, they also found that belatacept was associated with higher rates of acute cellular rejection within the first year posttransplant [3, 4]. Subsequently, alternative non-FDA approved belatacept-based maintenance regimens were explored including: (1) later post-transplant conversion from CNI to belatacept; (2) combination of belatacept plus a mammalian target of rapamycin inhibitor (MTORI); (3) belatacept plus transient $\mathrm{CNI}$; and (4) T cell-depletive induction followed by belatacept plus MMF and early corticosteroid withdrawal [1]. All these strategies were described in a kidney transplant population. Belatacept carries multiple black box warnings (BBW). The first BBW concerns increased risk of development of post-transplant lymphoproliferative disorders (PTLD) in those seronegative for EBV. As such, EBV seropositive status should be confirmed in all patients in whom belatacept is considered. The second BBW advises against use in liver transplantation due to an exploratory phase II study showing increased risk of death and graft loss within 6 months post-transplant [5]. The mechanism explaining this association in liver transplantation remains unclear and has not been observed within the other transplanted organ populations.

Data supporting the use of belatacept in non-abdominal organs are limited to case series and small cohorts involving patients requiring conversion due to $\mathrm{CNI}$ intolerance or contraindication. Clinical trials evaluating de novo use of belatacept in lung transplantation are currently underway [6]. Robust review articles summarizing the efficacy of belatacept salvage therapy in lung transplantation have previously been published, however, there exists little guidance on dosing selection [2]. This article reviews published belatacept dosing regimens to provide a framework for dosing selection in lung transplant recipients (LTRs) requiring conversion.

\section{Indications for Salvage Therapy in Lung Transplant}

Belatacept has no FDA approved indications for use in LTRs. However, belatacept has been used in LTRs for the purpose of renal sparing when alternative therapies were ineffective or when contraindications to CNIs exist. Additionally, the utility of belatacept in patients with donor specific 
antibodies (DSAs) and chronic antibody mediated rejection (AMR) has been explored within the kidney transplant literature.

\subsection{Renal Sparing}

While CNIs are standard of care for prevention of rejection, they are associated with chronic renal dysfunction through constriction of the afferent renal artery. Prevalence of chronic kidney disease stage $\geq 3$ is $22.4 \%$ at one year and $~ 50 \%$ at five years post-lung transplant $[7,8]$. When compared to kidney transplant recipients, LTRs are maintained at higher CNI goals due to increased immunologic risk [9]. Post-transplant tacrolimus goals at our center are $10-15 \mathrm{ng} / \mathrm{mL}$ for the first 90 days, 8-12 ng/mL for days $91-365,5-10 \mathrm{ng} / \mathrm{mL}$ for years $1-3$, and tapered to $5-8 \mathrm{ng} / \mathrm{mL}$ thereafter. In kidney transplantation, MTORIs are recommended for renal sparing either through replacement of $\mathrm{CNI}$ or combination therapy with minimized CNI. Recommendation of belatacept over MTORIs for the purpose of renal sparing cannot be provided due to lack of efficacy data. However, MTORIs are poorly tolerated due to issues with impairment of wound healing, proteinuria, hypertriglyceridemia, cytopenias, peripheral edema, or pneumonitis. In the event an LTR cannot tolerate MTORI, belatacept may be an appropriate option to consider.

\section{$2.2 \mathrm{CNI}$ Intolerance}

In thrombotic thrombocytopenia purpura (TTP), hemolytic uremic syndrome (HUS), or posterior reversible encephalopathy syndrome (PRES), re-challenging a CNI may not be ideal [10-12]. These complications generally occur in the immediate post-transplant phase, during which MTORI cannot be utilized. Reliance on belatacept for maintenance immunosuppression within the early posttransplant period compromises increased rejection risk. During instances of CNI contraindication, concurrent timely withdrawal of the CNI with up titration of the replacement agent is ideal.

\subsection{Donor Specific Antibodies/Antibody Mediated Rejection}

Post hoc analysis of data from the BENEFIT and BENEFIT-EXT trials have demonstrated both significantly lower $d n D S A$ formation in patients receiving belatacept versus cyclosporine, and better control of persistence of preexisting DSAs posttransplant as determined by MFI [13, 14]. These findings spurred further exploration into the utility of belatacept in patients with DSAs/AMR [15, 16]. Specifically, Kumar et al. reported a reduced rate of decline in renal function and a numerical nonsignificant decline in mean immunodominant DSA post-belatacept conversion in 19 kidney recipients with chronic active AMR [17]. DSA incidence at any time post-transplant in LTRs (26-47\%) is significantly higher than in kidney transplantation (2-5\% per year) [18-20]. Conversion to belatacept for treatment of DSAs/AMR is not directly supported within the literature. However, LTRs who are unable to tolerate augmented $\mathrm{CNI}$ goals due to chronic kidney disease, full dose MMF due to cytopenias, or immune-depletive therapies due to infections may benefit from a more targeted/alternative maintenance immunosuppression regimen.

\subsection{Absorption Concerns}

LTRs commonly experience post-transplant gastroesophageal reflux disease (GERD) and gastroparesis. These abdominal complications are associated with decline in lung function, and have 
been identified as possible causes of CLAD [21]. Unique subsets of patients transplanted for either interstitial lung disease or pulmonary hypertension include those with connective tissue disorders (i.e. scleroderma or sarcoidosis). Because both scleroderma and sarcoidosis are autoimmune disorders, lung transplantation is not curative, but rather, provides patients with functional respiratory reserve and subsequent improvement in mortality. Post-transplantation, these patients are at exquisitely high risk for chronic aspiration, malnutrition, and absorption concerns. It is possible that use of belatacept may be advantageous in patients with absorption concerns who have difficulties maintaining stable CNI levels. However, this hypothesis requires further exploration.

\section{Precautions for Use}

Given the paucity and heterogenous nature of existing data, it is unclear what long-term safety concerns may exist with use of belatacept in lung transplantation. Recent studies in kidney transplantation have highlighted the risk of CMV infections with belatacept. One study found highrisk (donor CMV IgG seropositive, recipient CMV IgG seronegative) kidney transplant recipients treated with a belatacept-based regimen experienced a higher incidence of CMV viremia, and a nonsignificant trend towards higher risk of graft loss [22]. A second study found that CMV disease occurred in $18 \%$ of kidney transplant recipients converted to belatacept (median nine months postconversion, median 30 months post-transplant) with $73 \%$ of these cases occurring in low (both donor and recipient CMV IgG seronegative) or intermediate risk (recipient CMV IgG seropositive) patients [23]. However, 38/40 patients who developed CMV disease were not receiving prophylaxis at time of disease diagnosis (median time from prophylaxis discontinuation to CMV disease of 26 months). It may be reasonable to continue CMV prophylaxis in LTRs receiving belatacept, or utilize CMV T-cell immunity panel monitoring to guide prophylaxis duration.

Belatacept resistant rejection (BRR) episodes have been described in kidney transplant recipients, and warrants precaution. The exact mechanism of resistance has yet to be elucidated and appears to be multifactorial. One theory behind BRR is that even with intensive loading and high-dose maintenance regimens, inhibition of T-cell proliferation is unlikely to exceed $70 \%$. Though significantly diminished, low level proliferation, differentiation, and development of memory T-cells continues to occur. Secondly, belatacept exposure may induce CD28 downregulation and increase production of memory T-cells which are not susceptible to co-stimulation blockade. These memory T-cells may also have a higher inclination for allograft infiltration due to increased expression of cellular adhesion molecules [24]. Certain populations of memory T-cells have been implicated in the development of BRR and novel, targeted therapeutics are currently under development in an attempt to abate the deleterious effects attributed to belatacept resistant memory T-cells [25].

\section{Dosing Schemes}

Belatacept dosing is comprised of an induction (or initial) and maintenance phase. The most common induction doses are $10 \mathrm{mg} / \mathrm{kg}$ IV or $5 \mathrm{mg} / \mathrm{kg}$ IV x 3-6 doses, given on specific post-transplant days. Belatacept demonstrates linear pharmacokinetics with steady state achieved by week eight in the induction phase and by month six in the maintenance (i.e. without induction phase) [26]. Induction doses for belatacept are recommended to reach $>90 \%$ CD86 receptor occupancy (\% occupied-CD86) for maximal inhibition of lymphocyte proliferation and cytokine interferon- $\gamma$ production in vitro; this was specifically studied using a dosing scheme of $10 \mathrm{mg} / \mathrm{kg} x$ ten doses 
within the context of de novo use to prevent acute rejection during allograft engraftment [27]. The in vitro difference in \% occupied-CD86 between the $10 \mathrm{mg} / \mathrm{kg} \times$ ten doses, $10 \mathrm{mg} / \mathrm{kg} \times$ four doses, and $5 \mathrm{mg} / \mathrm{kg}$ loading doses $x$ four doses was not directly compared, however, the $10 \mathrm{mg} / \mathrm{kg}$ dosing scheme achieved trough concentrations two to three times greater than the $5 \mathrm{mg} / \mathrm{kg}$ scheme. The \% occupied-CD86 receptors over time decreased to $94,88,86,75,67 \%$ at post-transplant days 5, 14, $28,84,168$, and 184 , respectively, during the maintenance phase. It is important to note that there is no recommended minimum \% occupied-CD86 corresponding with adequate level of immunosuppression. This in vitro data demonstrates that increasing belatacept exposure and dosing regimen does not protect against acute rejection within kidney transplant recipients in the immediate post-transplant phase. Use of the higher dosing regimen (i.e. ten loading doses) was also associated with an increased risk of serious adverse effect [28]. Specifically, administration of higher cumulative doses (greater than $20 \mathrm{mg} / \mathrm{kg}$ per single dose) or higher frequency (more frequently than monthly following the initial loading period) should be avoided based on observed higher incidence of central nervous system (CNS) adverse reactions including PTLD, progressive multifocal leukoencephalopathy (PML), and serious infections. While these adverse effects occurred more frequently in EBV seronegative patients-ultimately leading to the inclusion of the BBW-total burden of immunosuppression remains an overall risk factor for PTLD and should be considered.

Across all solid organ transplant patients being converted to belatacept, there is concern for both under- and over-immunosuppression. Ensuring the timely discontinuation of the intended agent without excessive or inadequate overlap appears to be more art than science at this point. The previously published belatacept induction and maintenance doses are compiled in Table 1 and Table 2 respectively. Even within the same indications, dosing schemes varied.

Table 1 Published belatacept induction doses.

\begin{tabular}{|c|c|c|c|c|}
\hline Indication & Study & Organ & $\mathbf{N}$ & Induction Dose \\
\hline \multicolumn{5}{|l|}{ Non-Abdominal } \\
\hline \multirow{2}{*}{$\begin{array}{l}\text { Renal Rescue } \\
\text { CNI Failure }\end{array}$} & Timofte et al. [29] & Lung & 8 & $10 \mathrm{mg} / \mathrm{kg} \times 4$ doses \\
\hline & lasella et al. [30] & Lung & 11 & Conventional: $10 \mathrm{mg} / \mathrm{kg} \times 6$ doses \\
\hline \multirow[t]{2}{*}{$\begin{array}{l}\text { (TTP, } \\
\text { HUS) }\end{array}$} & & & & $\begin{array}{l}\text { Transitional: } 5 \mathrm{mg} / \mathrm{kg} \text { every } 2 \text { weeks } \times 6 \\
\text { doses }\end{array}$ \\
\hline & Hui et al. [31] & Lung & 1 & $10 \mathrm{mg} / \mathrm{kg}$ IV $\times 1$ dose \\
\hline Non-adherence & Enderby et al. [32] & Heart & 1 & $10 \mathrm{mg} / \mathrm{kg} \times 4$ doses \\
\hline \multicolumn{5}{|l|}{ Abdominal } \\
\hline \multirow[t]{4}{*}{ De novo } & Vincenti et al. $[3,4]$ & & 686 & Moderate intensity: $10 \mathrm{mg} / \mathrm{kg} \times 10$ \\
\hline & & Kidney & & doses \\
\hline & & & & Low Intensity: 10 mg/kg x 4 doses \\
\hline & Grinyo et al. [33] & Kidney & 162 & $5 \mathrm{mg} / \mathrm{kg} \times 5$ doses \\
\hline$<6$ months from & Nair et al. [34] & Kidney & 16 & $10 \mathrm{mg} / \mathrm{kg} \times 4$ doses \\
\hline TXP & Le Meur et al. [35] & Kidney & 25 & $5 \mathrm{mg} / \mathrm{kg}$ every 2 weeks $\times 6$ doses \\
\hline Prolonged DGF & $\begin{array}{l}\text { Wojciechowski et } \\
\text { al. [36] }\end{array}$ & Kidney & 20 & $10 \mathrm{mg} / \mathrm{kg} \times 3$ doses \\
\hline $\begin{array}{l}\text { CNI Failure } \\
\text { (TMA) }\end{array}$ & $\begin{array}{l}\text { Brakemeier et al. } \\
{[37]}\end{array}$ & Kidney & 70 & $\begin{array}{l}5 \mathrm{mg} / \mathrm{kg} \times 5 \text { doses } \\
\text { CNI-induced TMA: } 10 \mathrm{mg} / \mathrm{kg} \times 4 \text { doses }\end{array}$ \\
\hline
\end{tabular}




\begin{tabular}{lllll} 
Conversion & Schulte et al. [38] & Kidney & 20 & $5 \mathrm{mg} / \mathrm{kg}$ every 2 weeks $\times 4$ doses \\
& Gupta et al. [39] & Kidney & 6 & $5 \mathrm{mg} / \mathrm{kg} \times 5$ doses \\
& Rostaing et al. [40] & Kidney & 173 & $5 \mathrm{mg} / \mathrm{kg} \times 5$ doses \\
\hline
\end{tabular}

CNI, calcineurin inhibitor; TTP, thrombotic thrombocytopenia purpura; PRES, posterior reversible encephalopathic syndrome; HUS, hemolytic uremic syndrome; TXP, transplant; DGF, delayed graft function; TMA, thrombotic microangiopathy

Table 2 Published belatacept maintenance doses.

\begin{tabular}{|c|c|c|c|c|}
\hline Indication & Study & Organ & $\mathbf{N}$ & Maintenance Dose \\
\hline \multicolumn{5}{|l|}{ Non-Abdominal } \\
\hline \multirow{2}{*}{$\begin{array}{l}\text { Renal Rescue } \\
\text { CNI Failure }\end{array}$} & Timofte et al. [29] & Lung & 8 & $10 \mathrm{mg} / \mathrm{kg}+\mathrm{CNI}$ goal $2-6 \mathrm{ng} / \mathrm{mL}$ \\
\hline & lasella et al. [30] & Lung & 11 & Conventional: $5 \mathrm{mg} / \mathrm{kg}$ monthly \\
\hline \multirow{3}{*}{$\begin{array}{l}\text { (TTP, } \\
\text { HUS) }\end{array}$} & & & & Transitional: 5 mg/kg monthly \\
\hline & Hui et al. [31] & Lung & 1 & $5 \mathrm{mg} / \mathrm{kg}$ every 4 weeks \\
\hline & Ong et al. [41] & Lung & 1 & $5 \mathrm{mg} / \mathrm{kg}$ every 2 weeks \\
\hline Non-adherence & Enderby et al. [32] & Heart & 1 & $5 \mathrm{mg} / \mathrm{kg}$ every 4 weeks \\
\hline \multicolumn{5}{|l|}{ Abdominal } \\
\hline \multirow[t]{2}{*}{ De novo } & Vincenti et al. $[3,4]$ & Kidney & 686 & $\begin{array}{l}\text { Moderate intensity: } 5 \mathrm{mg} / \mathrm{kg} \\
\text { every } 4 \text { or } 8 \text { weeks } \\
\text { Low Intensity: } 5 \mathrm{mg} / \mathrm{kg} \text { every } 4 \\
\text { weeks }\end{array}$ \\
\hline & Grinyo et al. [33] & Kidney & 162 & $\begin{array}{l}5 \mathrm{mg} / \mathrm{kg} \text { every } 4 \text { weeks }+\mathrm{CNI} \\
\text { discontinued by day } 29\end{array}$ \\
\hline \multirow[t]{2}{*}{$\begin{array}{l}<6 \text { months from } \\
\text { TXP }\end{array}$} & Nair et al. [34] & Kidney & 16 & $\begin{array}{l}5 \mathrm{mg} / \mathrm{kg} \text { every } 4 \text { weeks }+\mathrm{CNI} \\
\text { tapered with maintenance dose } \\
1 \text { or } 2\end{array}$ \\
\hline & Le Meur et al. [35] & Kidney & 25 & $\begin{array}{l}5 \mathrm{mg} / \mathrm{kg} \text { every } 4 \text { weeks }+\mathrm{CNI} \\
\text { withdrawn over } 15-30 \text { days }\end{array}$ \\
\hline Prolonged DGF & Wojciechowski et al. [36] & Kidney & 20 & $\begin{array}{l}5 \mathrm{mg} / \mathrm{kg} \text { monthly }+ \text { FK } 8-12 \text { on } \\
\text { D0-13, then } 50 \% \text { on day } 14 \text {, then } \\
\text { off by day } 28\end{array}$ \\
\hline \multirow{4}{*}{$\begin{array}{l}\text { CNI Failure } \\
\text { (TMA) } \\
\text { Conversion }\end{array}$} & Brakemeier et al. [37] & Kidney & 70 & $\begin{array}{l}5 \mathrm{mg} / \mathrm{kg} \text { every } 4 \text { weeks }+\mathrm{CNI} \text { off } \\
\text { by day } 180\end{array}$ \\
\hline & Schulte et al. [38] & Kidney & 20 & $\begin{array}{l}5 \mathrm{mg} / \mathrm{kg} \text { every } 4 \text { weeks }+\mathrm{CNI} \text { off } \\
\text { by day } 180\end{array}$ \\
\hline & Gupta et al. [39] & Kidney & 6 & $\begin{array}{l}5 \mathrm{mg} / \mathrm{kg} \text { every } 4 \text { weeks then } \mathrm{CNI} \\
\text { off by day } 42\end{array}$ \\
\hline & Rostaing et al. [40] & Kidney & 173 & $\begin{array}{l}5 \mathrm{mg} / \mathrm{kg} \text { every } 4 \text { weeks }+\mathrm{CNI} \text { off } \\
\text { by day } 29\end{array}$ \\
\hline
\end{tabular}

CNI, calcineurin inhibitor; TTP, thrombotic thrombocytopenia purpura; PRES, posterior reversible encephalopathic syndrome; HUS, hemolytic uremic syndrome; TXP, transplant; DGF, delayed graft function; TMA, thrombotic microangiopathy 


\section{Four Drug Maintenance Versus Replacement}

An important decision to make when transitioning to belatacept in lung transplant recipients is determining which agent to discontinue. Four drug maintenance regimens can be used in patients at high immunologic risk, but there is little evidence to recommend this in lung transplantation due to significant infection risk. Because infection is the leading cause of mortality within the first year post-lung transplant [42], avoiding overimmunosuppression with a four drug maintenance regimen is advised, but can be considered in patients with recurrent rejection. While chronic allograft dysfunction and chronic rejection supplant infection as the leading cause of death beyond the first year [43], the relative risk between rejection and infection should take into account patient-specific post-transplant courses. When determining which agent to discontinue, the indication for salvage therapy should also guide selection.

\section{Proposed Dosing Selection Algorithm}

With the abundance of varying published dosing protocols, our center has developed an algorithm to assist in selection of belatacept dosing (Figure 1). Through a series of three questions, the transplant clinician evaluates a patient's immunologic versus infection risk.

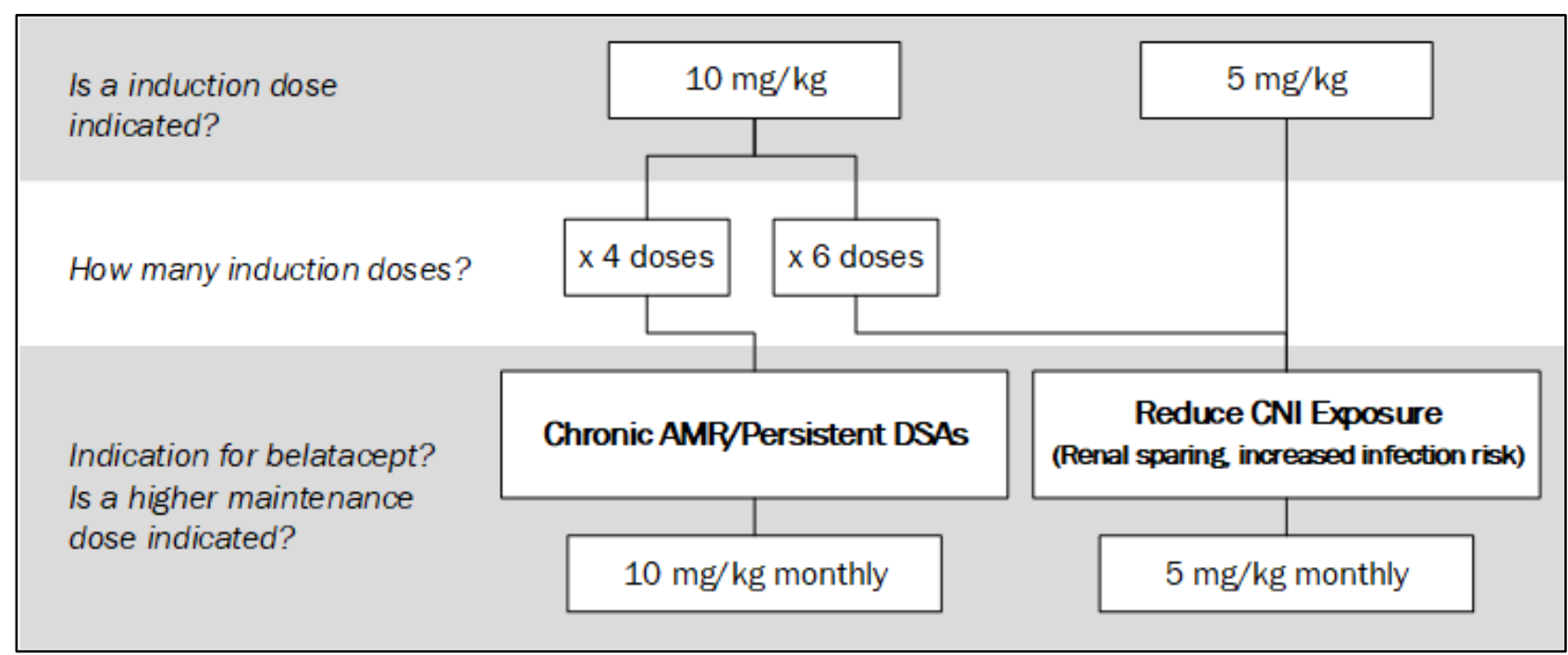

Figure 1 Belatacept dosing selection algorithm.

The questions to consider are:

1) Is an induction dose indicated? Consider the patient's immune risk (rejection history, persistence of DSAs) versus infection risk (frailty, infection history). Can this patient tolerate a brief period of time where they may be over immunosuppressed?

2) If an induction dose is indicated, how many should the patient receive? If a patient will be maintained on a higher monthly dose (i.e. $10 \mathrm{mg} / \mathrm{kg}$ ), they will likely only need four induction doses.

3) What is the indication for belatacept? Is a higher maintenance dose indicated? Consider the patient's long term goals (i.e. better control of immune outcomes versus reduction in CNI exposure).

Other general conversion considerations include:

- The agent intended to be discontinued must be tapered off slowly to prevent subtherapeutic immunosuppression. 
- The agent intended to be discontinued should be stopped after all induction doses have been given.

At this point in time, there are no data to compare efficacy between three drug maintenance regimens with (1) prednisone, (2) belatacept, and (3) an antimetabolite, CNI, or MTORI. Our center has elected to continue minimized $\mathrm{CNI}$ in combination with belatacept, unless the $\mathrm{CNI}$ is contraindicated. We are hesitant to completely withdraw CNIs due to the superior rejection protection they provide. Additionally, given the aforementioned incomplete inhibition of T-cell proliferation and persistence of memory T-cell activity, our approach has been to minimize but not remove $\mathrm{CNI}$ from our maintenance regimen outside of clinical trial or absolute intolerance of CNI.

To both conceptualize the conversion schedule and provide a framework for consistent conversion, we developed dosing guidance schematics (Figures 2-5). Depending on the desired induction and maintenance doses, the time frame for conversion and overall state of immunosuppression varies.

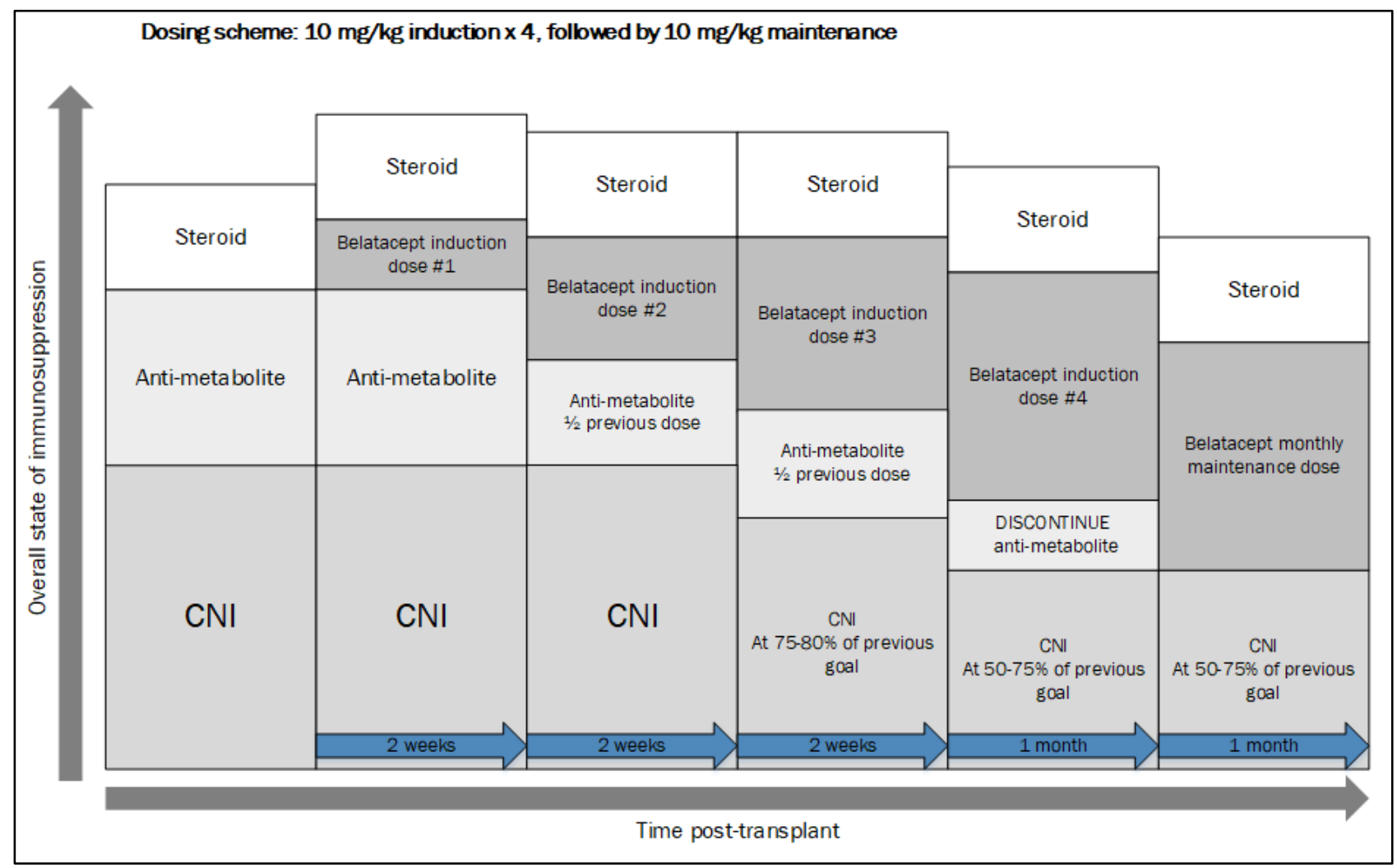

Figure 2 Conversion schematic-10 $\mathrm{mg} / \mathrm{kg}$ induction $\times 4$, followed by $10 \mathrm{mg} / \mathrm{kg}$ maintenance. 


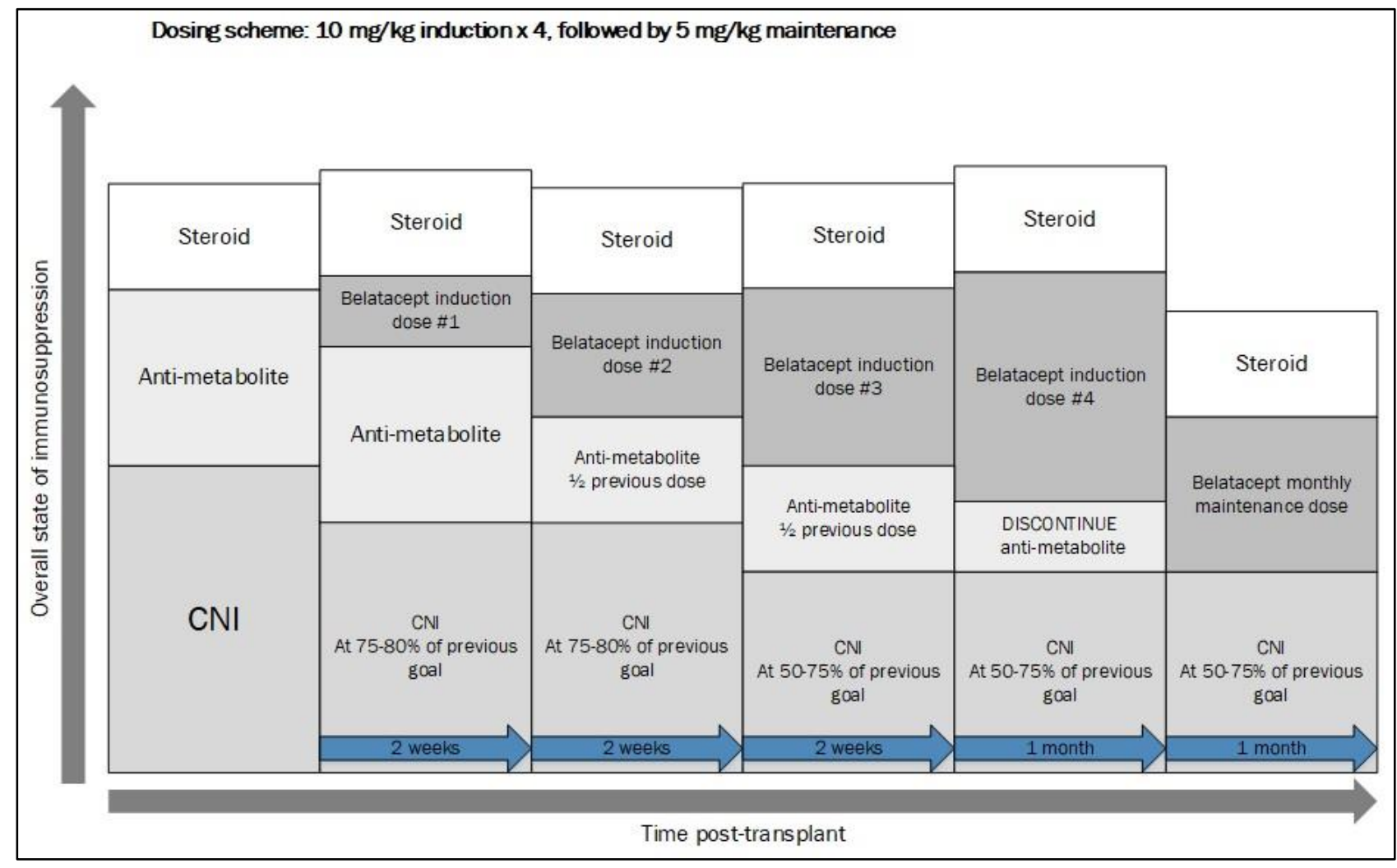

Figure 3 Conversion schematic-10 $\mathrm{mg} / \mathrm{kg}$ induction $x 4$, followed by $5 \mathrm{mg} / \mathrm{kg}$ maintenance.

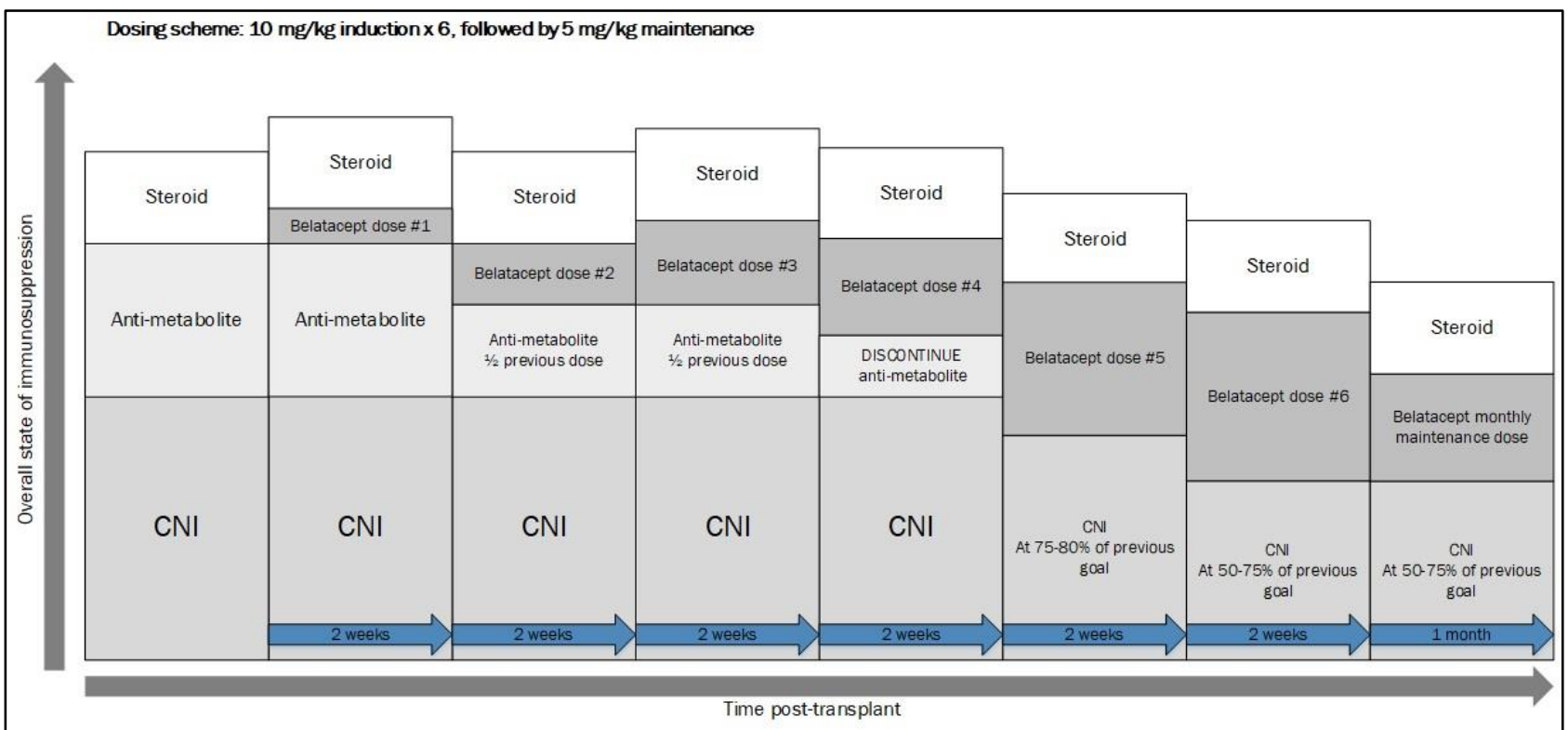

Figure 4 Conversion schematic-10 $\mathrm{mg} / \mathrm{kg}$ induction $\times 6$, followed by $5 \mathrm{mg} / \mathrm{kg}$ maintenance. 


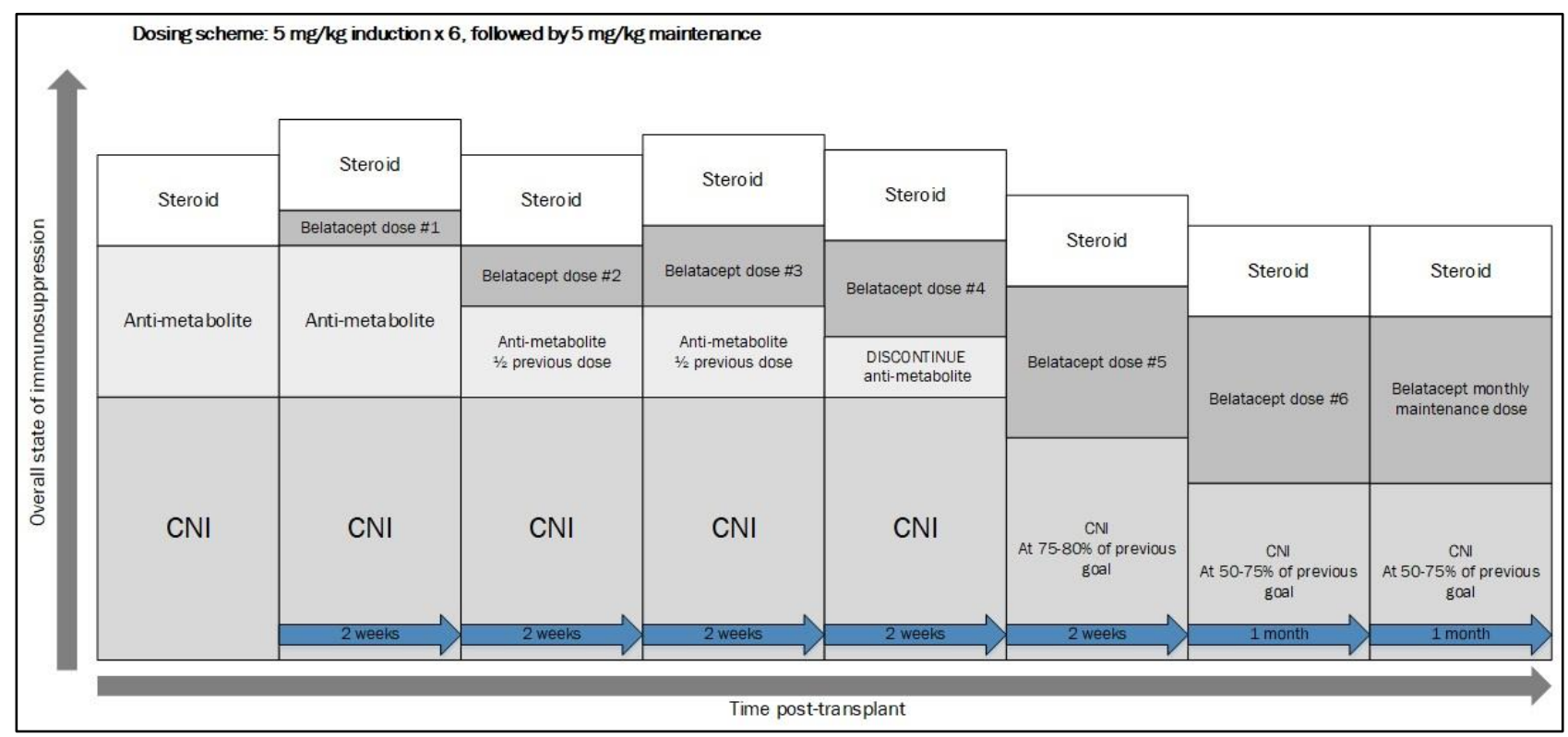

Figure 5 Conversion schematic $-5 \mathrm{mg} / \mathrm{kg}$ induction $\times 6$, followed by $5 \mathrm{mg} / \mathrm{kg}$ maintenance.

If an absolute contraindication to CNI exists, the CNI should be discontinued immediately and selection of a belatacept dosing scheme with induction doses should be considered in order to achieve steady state quicker. The MTORI or antimetabolite should be continued at full dose in conjunction with belatacept and a steroid as part of a CNI-free maintenance regimen.

\section{Future Directions}

Prospective randomized controlled trials evaluating belatacept dosing schemes are needed. Only one retrospective study has been published characterizing 13 belatacept conversion protocols in 78 kidney transplant recipients across a single integrated health care organization [44]. The authors evaluated rejection within 6 months post-belatacept conversion, then analysed for baseline characteristics associated with rejection. Although efficacy and safety of the numerous conversion protocols was not directly assessed, the authors noted no observed association of rejection with any specific protocol, tacrolimus tapering regimen, presence of DSA, or pre-conversion rejection.

As belatacept utilization continues to increase in non-kidney transplant recipients, long term outcomes will need to be reported upon. Other possible avenues for assessing appropriateness of immunosuppression between dosing schemes include in vitro testing to compare CD86 receptor occupancy, belatacept therapeutic drug monitoring, or measurement of donor derived cell-free DNA. In addition to direct assessment of dosing, research centered on clinical outcomes after belatacept conversion (i.e. renal function, rejection, DSAs, longitudinal lung function) are of top priority. Ultimately, consistent belatacept dosing using conversion protocols will improve the ability to directly assess outcomes and improve patient care.

\section{Author Contributions}

C Pham and B Pierce participated in conception of work, compilation of prior published literature, writing of manuscript, and revision of work. SW Yau, A Goodarzi, GJ Youssef, and HJ Huang participated in revising of work for important intellectual content. 


\section{Competing Interests}

The authors have declared that no competing interests exist.

\section{References}

1. Kirk $A D$, Adams $A B$, Durrbach $A$, Ford ML, Hildeman DA, Larsen $C P$, et al. Optimization of de novo belatacept-based immunosuppression administered to renal transplant recipients. Am J Transplant. 2021; 21: 1691-1698.

2. Perez CP, Patel N, Mardis CR, Meadows HB, Taber DJ, Pilch NA. Belatacept in solid organ transplant: Review of current literature across transplant types. Transplantation. 2018; 102: 1440-1452.

3. Vincenti F, Charpentier B, Vanrenterghem Y, Rostaing L, Bresnahan B, Darji P, et al. A phase III study of belatacept-based immunosuppression regimens versus cyclosporine in renal transplant recipients (BENEFIT study). Am J Transplant. 2010; 10: 535-546.

4. Durrbach A, Pestana JM, Pearson T, Vincenti F, Garcia VD, Campistol J, et al. A phase III study of belatacept versus cyclosporine in kidney transplants from extended criteria donors (BENEFITEXT study). Am J Transplant. 2010; 10: 547-557.

5. Klintmalm GB, Feng S, Lake JR, Vargas HE, Wekerle T, Agnes S, et al. Belatacept-based immunosuppression in de novo liver transplant recipients: 1-year experience from a phase II randomized study. Am J Transplant. 2014; 14: 1817-1827.

6. Washington University School of Medicine. Belatacept pilot study in lung transplantation immunosuppression in lung transplantation [Internet]. Bethesda: Clinicaltrials.gov.; 2021. Available

from: https://www.clinicaltrials.gov/ct2/show/NCT03388008?cond=belatacept+lung+transplant\&dr aw $=2 \&$ rank $=2$.

7. Lund LH, Edwards LB, Kucheryavaya AY, Benden C, Dipchand Al, Goldfarb S, et al. The registry of the international society for heart and lung transplantation: Thirty-second official adult heart transplantation report-2015; focus theme: Early graft failure. J Heart Lung Transplan. 2015; 34: 1244-1254.

8. Florens N, Dubourg L, Bitker L, Kalbacher E, Philit F, Mornex JF, et al. Measurement of glomerular filtration rate in lung transplant recipients highlights a dramatic loss of renal function after transplantation. Clin kidney J. 2020; 13: 828-833.

9. Monchaud C, Marquet P. Pharmacokinetic optimization of immunosuppressive therapy in thoracic transplantation: Part I. Clin Pharmacokinet. 2009; 48: 419-462.

10. Garg N, Rennke HG, Pavlakis M, Zandi-Nejad K. De novo thrombotic microangiopathy after kidney transplantation. Transplant Rev. 2018; 32: 58-68.

11. Ali MN, Syed AB, Bhandari SC. Case series: Hemolytic uremic syndrome-another cause of transplant dysfunction. Transplant Proc. 2013; 45: 3284-3288.

12. Chen S, Hu J, Xu L, Brandon D, Yu J, Zhang J. Posterior reversible encephalopathy syndrome after transplantation: A review. Mol Neurobiol. 2016; 53: 6897-6909.

13. Bray RA, Gebel HM, Townsend R, Roberts ME, Polinsky M, Yang L, et al. De novo donor-specific antibodies in belatacept-treated vs cyclosporine-treated kidney-transplant recipients: Post hoc 
analyses of the randomized phase III BENEFIT and BENEFIT-EXT studies. Am J Transplant. 2018; 18: 1783-1789.

14. Bray RA, Gebel HM, Townsend R, Roberts ME, Polinsky M, Yang L, et al. Posttransplant reduction in preexisting donor-specific antibody levels after belatacept-versus cyclosporinebased immunosuppression: Post hoc analyses of BENEFIT and BENEFIT-EXT. Am J Transplant. 2018; 18: 1774-1782.

15. Kim EJ, Kwun J, Gibby AC, Hong JJ, Farris III AB, Iwakoshi NN, et al. Costimulation blockade alters germinal center responses and prevents antibody-mediated rejection. Am J Transplant. 2014; 14: 59-69.

16. Jain D, Rajab A, Young JS, Yin D, Nadasdy T, Chong AS, et al. Reversing donor-specific antibody responses and antibody-mediated rejection with bortezomib and belatacept in mice and kidney transplant recipients. Am J Transplant. 2020; 20: 2675-2685.

17. Kumar D, Raynaud M, Chang J, Reeve J, Yakubu I, Kamal L, et al. Impact of belatacept conversion on renal function, histology, and gene expression in kidney transplant patients with chronic active antibody-mediated rejection. Transplantation. 2021; 105: 660-667.

18. Schmitzer $M$, Winter $H$, Kneidinger $N$, Meimarakis $G$, Dick $A$, Schramm $R$, et al. Persistence of de novo donor-specific HLA-antibodies after lung transplantation: A potential marker of decreased patient survival. HLA. 2018; 92: 24-32.

19. Wiebe C, Gibson IW, Blydt-Hansen TD, Pochinco D, Birk PE, Ho J, et al. Rates and determinants of progression to graft failure in kidney allograft recipients with de novo donor-specific antibody. Am J Transplant. 2015; 15: 2921-2930.

20. Cun H, Hönger G, Kleiser M, Amico P, Wehmeier C, Steiger J, et al. Screening strategy for de novo donor-specific HLA antibodies beyond the first year after kidney transplantation: Personalized or "one size fits all"? Clin Transplant. 2021; 35: e14170.

21. de Pablo A, Alonso R, Ciriza C, Lopez E, Canga F, Juarros L, et al. Gastroesophageal reflux and esophageal motility disorder after lung transplant: Influence on the transplanted graft. TransplantProc. 2021; 53: 1989-1997.

22. Karadkhele G, Hogan J, Magua W, Zhang W, Badell IR, Mehta A, et al. CMV high-risk status and posttransplant outcomes in kidney transplant recipients treated with belatacept. Am J Transplant. 2021; 21: 208-221.

23. Chavarot N, Divard G, Scemla A, Amrouche L, Aubert O, Leruez-Ville M, et al. Increased incidence and unusual presentations of CMV disease in kidney transplant recipients after conversion to belatacept. Am J Transplant. 2021; 21: 2448-2458.

24. Kumar J, Reccia I, Virdis F, Podda M, Sharma AK, Halawa A. Belatacept in renal transplantation in comparison to tacrolimus and molecular understanding of resistance pattern: Meta-analysis and systematic review. World J Transplant. 2021; 11: 70-86.

25. Sun $H$, Hartigan CR, Chen CW, Sun Y, Tariq M, Robertson JM, et al. TIGIT regulates apoptosis of risky memory T cell subsets implicated in belatacept-resistant rejection. Am J Transplant. 2021. Doi: 10.1111/ajt.16571.

26. Belatacept (Nulojix ${ }^{\oplus}$ ). Package insert. Princeton: Bistol-Myers Squibb; 2014.

27. Shen J, Townsend R, You X, Shen Y, Zhan P, Zhou Z, et al. Pharmacokinetics, pharmacodynamics, and immunogenicity of belatacept in adult kidney transplant recipients. Clin Drug Investig. 2014; 34: 117-126. 
28. Zhou Z, Shen J, Hong Y, Kaul S, Pfister M, Roy A. Time-varying belatacept exposure and its relationship to efficacy/safety responses in kidney-transplant recipients. Clin Pharmacol Ther. 2012; 92: 251-257.

29. Timofte I, Terrin M, Barr E, Sanchez P, Kim J, Reed R, et al. Belatacept for renal rescue in lung transplant patients. Transplant Int. 2016; 29: 453-463.

30. Iasella CJ, Winstead RJ, Moore CA, Johnson BA, Feinberg AT, Morrell MR, et al. Maintenance belatacept-based immunosuppression in lung transplantation recipients who failed calcineurin inhibitors. Transplantation. 2018; 102: 171-177.

31. Hui C, Kern R, Wojciechowski D, Kukreja J, Golden JA, Hays SR, et al. Belatacept for maintenance immunosuppression in lung transplantation. J Investig Med High Impact Case Rep. 2014; 2: 2324709614546866.

32. Enderby CY, Habib P, Patel PC, Yip DS, Orum S, Hosenpud JD. Belatacept maintenance in a heart transplant recipient. Transplantation. 2014; 98: e74-e75.

33. Grinyó JM, del Carmen Rial M, Alberu J, Steinberg SM, Manfro RC, Nainan G, et al. Safety and efficacy outcomes 3 years after switching to belatacept from a calcineurin inhibitor in kidney transplant recipients: Results from a phase 2 randomized trial. Am J Kidney Dis. 2017; 69: 587594.

34. Nair V, Liriano-Ward L, Kent R, Huprikar S, Rana M, Florman SS, et al. Early conversion to belatacept after renal transplantation. Clin Transplant. 2017; 31: e12951.

35. Le Meur Y, Aulagnon F, Bertrand D, Heng AE, Lavaud S, Caillard S, et al. Effect of an early switch to belatacept among calcineurin inhibitor-intolerant graft recipients of kidneys from extendedcriteria donors. Am J Transplant. 2016; 16: 2181-2186.

36. Wojciechowski D, Chandran S, Vincenti F. Early post-transplant conversion from tacrolimus to belatacept for prolonged delayed graft function improves renal function in kidney transplant recipients. Clin Transplant. 2017; 31: e12930.

37. Brakemeier S, Kannenkeril D, Dürr M, Braun T, Bachmann F, Schmidt D, et al. Experience with belatacept rescue therapy in kidney transplant recipients. Transplant Int. 2016; 29: 1184-1195.

38. Schulte K, Vollmer C, Klasen V, Bräsen JH, Püchel J, Borzikowsky C, et al. Late conversion from tacrolimus to a belatacept-based immuno-suppression regime in kidney transplant recipients improves renal function, acid-base derangement and mineral-bone metabolism. J Nephrol. 2017; 30: 607-615.

39. Gupta G, Regmi A, Kumar D, Posner S, Posner MP, Sharma A, et al. Safe conversion from tacrolimus to belatacept in high immunologic risk kidney transplant recipients with allograft dysfunction. Am J Transplant. 2015; 15: 2726-2731.

40. Rostaing L, Vincenti F, Grinyo J, Rice KM, Bresnahan B, Steinberg S, et al. Long-term belatacept exposure maintains efficacy and safety at 5 years: Results from the long-term extension of the BENEFIT study. Am J Transplant. 2013; 13: 2875-2883.

41. Ong P, Mudambi L, Fuentes A, Dawson K, Sinha N, Mankidy B, et al. Belatacept as primary immunosuppression in a lung transplant recipient. J Heart Lung Transplant. 2014; 33: S31.

42. Fishman JA. Infection in organ transplantation. Am J Transplant. 2017; 17: 856-879.

43. Verleden GM, Glanville AR, Lease ED, Fisher AJ, Calabrese F, Corris PA, et al. Chronic lung allograft dysfunction: Definition, diagnostic criteria, and approaches to treatment-a consensus report from the Pulmonary Council of the ISHLT. J Heart Lung Transplant. 2019; 38: 493-503.

44. Yazdi M, Kahwaji JM, Meguerditchian S, Lee R. Belatacept conversion protocols and outcomes 
in kidney transplant recipients. Transplant Proc. 2021; 53: 976-983.

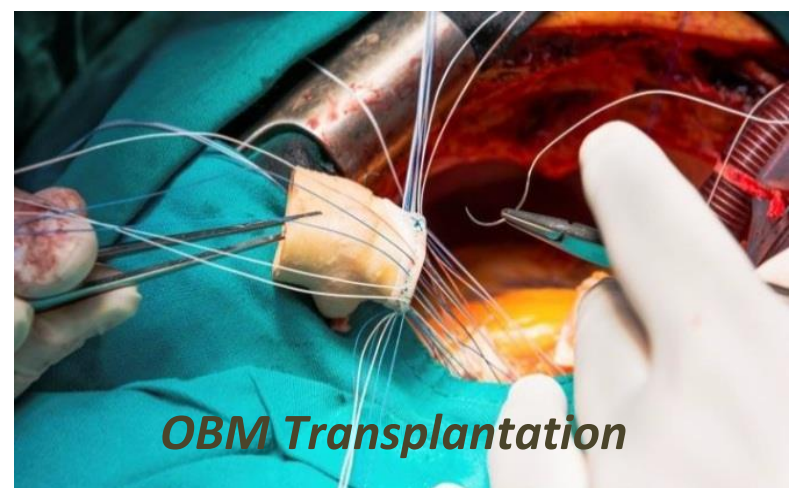

Enjoy $O B M$ Transplantation by:

1. Submitting a manuscript

2. Joining in volunteer reviewer bank

3. Joining Editorial Board

4. Guest editing a special issue

For more details, please visit:

http://www.lidsen.com/journals/transplantation 